\title{
Evaluation of Vetiver Grass Uptake Efficiency in Single and Mixed Heavy Metal Contaminated Soil
}

\author{
Chuck Chuan Ng ${ }^{1,2,3}$ (D) Amru Nasrulhaq Boyce ${ }^{2} \cdot$ Mhd Radzi Abas $^{4}$. \\ Noor Zalina Mahmood ${ }^{2}$. Fengxiang $\operatorname{Han}^{3}$
}

Received: 8 February 2019 / Accepted: 30 December 2019/Published online: 11 January 2020

(C) Springer Nature Switzerland AG 2020

\begin{abstract}
Most phyto-remediation studies have been conducted merely on a single type of contaminant element without consideration of the influence of other co-existent contaminants. In this study, Vetiveria zizanioides (Linn.) Nash was evaluated in both single and mixed heavy metal $(\mathrm{Cd}, \mathrm{Pb}, \mathrm{Cu}$ and $\mathrm{Zn})$ spiked contaminated soil. The plant growth, metal accumulation and overall efficiency of metal uptake by different plant parts (lower root, upper root, lower tiller and upper tiller) were investigated in detail. The relative growth performance, metal tolerance and phyto-assessment of heavy metal in roots and tillers of Vetiver grass were assessed. Metals in plants were measured using the flame atomic absorption spectrometry (F-AAS) after acid digestion. The root-tiller (R/T) ratio, tolerance index (TI), translocation factor (TF), biological concentration factor (BCF), biological accumulation coefficient (BAC) and metal uptake efficacy were estimated to examine the ability of metal accumulation and translocation in Vetiver grass. No significant difference $(p>0.05)$ of plant height was observed among all single and mixed heavy metal spiked soils compared with the control. However, significantly higher $(p<0.05)$ heavy metal $(\mathrm{Cd}, \mathrm{Pb}, \mathrm{Cu}$ and $\mathrm{Zn})$ accumulations were found in roots, tillers and overall total accumulation of the individual spiked metal as compared with other treatments. Vetiver grass grown in the mixed $\mathrm{Cd}+\mathrm{Pb}+\mathrm{Cu}+\mathrm{Zn}$ spiked soils accumulated the highest $\mathrm{Zn} \mathrm{(3322 \pm}$ $21.6 \mathrm{mg} / \mathrm{kg})$ followed by $\mathrm{Cu}(430 \pm 11.4 \mathrm{mg} / \mathrm{kg}), \mathrm{Pb}(197 \pm 13.5 \mathrm{mg} / \mathrm{kg})$ and $\mathrm{Cd}(100 \pm$ $0.7 \mathrm{mg} / \mathrm{kg}$ ). Vetiver grass grown in mixed $\mathrm{Cd}+\mathrm{Pb}, \mathrm{Cu}+\mathrm{Zn}$ and $\mathrm{Cd}+\mathrm{Pb}+\mathrm{Cu}+\mathrm{Zn}$ spiked soils accumulated higher heavy metal concentrations than from the single spiked soil with the following order of metals: $\mathrm{Zn}>>\mathrm{Cu}>\mathrm{Pb}>\mathrm{Cd}$. Moreover, lower roots and lower tillers of Vetiver grass revealed a strong tendency for greater uptake and accumulation of all four heavy metals in both single and/or mixed spiked contaminated soils.
\end{abstract}

Keywords Mixed heavy metal · Vetiver grass · Lower root · Upper root · Lower tiller - Upper tiller Contaminated soil $\cdot$ Heavy metal accumulation

Chuck Chuan Ng

chuckz89@gmail.com

Extended author information available on the last page of the article 


\section{Introduction}

Soil contamination has received global environmental attention as a result of its adverse effects on both human health and the environment (Doran 2002; Azam 2016; Gómez-Sagasti et al. 2016). Soil often becomes contaminated typically due to the past and present emissions from rapidly expanding industrial activities, agricultural chemical runoff and improper disposal of wastes (Waller 1982; Meuser 2010; Van der Perk 2013). The common sources of soil contaminants may include both organic (halogenated volatiles, non-halogenated volatiles, pesticides, dioxin, furan, poly-chlorinated biphenyl and cyanides) and inorganic (volatile metals, non-volatile metals and radioactive materials) components (Harris et al. 1995; Ali and Khan 2017). Among the various types of soil contamination, heavy metal contaminants have become concerns as heavy metals are freely available in soil materials (environment) and are highly hazardous to human health even in trace amounts (Storelli 2008; Martin and Griswold 2009; Clemens and Ma 2016; Ali et al. 2019). Generally, the term heavy metal is widely accepted to describe a group of naturally occurring metals in the periodic table which have an elemental density $>5 \mathrm{~g} / \mathrm{cm}^{3}$ and atomic number $>20$, which are often persistent in environmental bodies over a long duration and are mostly lethal (Gomes 2012; Kabata-Pendias 2010; Ali and Khan 2018a, b).

Heavy metals such as copper $(\mathrm{Cu})$, zinc $(\mathrm{Zn})$, iron (Fe), nickel (Ni) and manganese (Mn) are essential soil micronutrients required by living organisms in trace amounts for biological metabolic processes (Pilbeam and Barker 2007). Nevertheless, non-essential heavy metals like cadmium $(\mathrm{Cd})$, lead $(\mathrm{Pb})$, chromium $(\mathrm{Cr})$, arsenic $(\mathrm{As})$ and mercury $(\mathrm{Hg})$ are predominantly hazardous, and are not needed for the growth of living organisms. Naturally occurring heavy metals are usually untraceable, non-biodegradable and can easily bio-accumulate and affect human health through the food chain (Bradl 2005; Kamal et al. 2016; Ali and Khan $2018 \mathrm{a}, \mathrm{b}$ ). Among all the different types of heavy metals, $\mathrm{Cd}, \mathrm{Pb}, \mathrm{Cu}$ and $\mathrm{Zn}$ are the few commonly available metal found in the soil (Brümmer 1986; Wuana and Okieimen 2011; Alloway 2013). Soil contaminated by heavy metals may severely contribute to the inhibition of growth and reduced metabolic activities in plants over time (Antonovics et al. 1971; Nagajyoti et al. 2010).

As a consequence, soil remediation techniques (physical, chemical and biological remediation) for heavy metal contamination have been developed over the years (Garbisu and Alkorta 2003; Hasegawa et al. 2016). Nonetheless, phyto-remediation has successfully developed to be one of the most preferred techniques as a result of its simple, cost-effective and environmentally friendly approach (Ali et al. 2013; Mahar et al. 2016). Correspondingly, Vetiver grass, Vetiveria zizanioides (Linn.) Nash has been carefully selected among various types of plants based on the earlier research studies (Chen et al. 2004; Ng et al. 2017, 2018) to be the most favourable species due to its fast growing, deep and extensive root system, high tolerance towards environmental stress, and its ability to withstand extreme concentrations of a wide range of contaminant heavy metals (Danh et al. 2009; Truong and Danh 2015; Gnansounou et al. 2017; Raman and Gnansounou 2018; Darajeh et al. 2019; $\mathrm{Ng}$ et al. 2019). However, even though there is a growing interest on phyto-remediation of single and mixed heavy metal contaminated soils with Vetiver grass, it remains poorly studied and requires urgent elucidation. Over the years, little evidence has been made available on studies with mixed heavy metal contamination (Khalil et al. 1996; Peralta-Videa et al. 2002; Stolpe and Müller 2016; Yang et al. 2016; Ghadiri et al. 2018). Previous studies have solely emphasized on the limited types of heavy metals and inadequately explained phyto-assessment in the different plant parts. 
Therefore, the objectives of this study were to evaluate the growth performance, accumulation trend and efficiency of metal uptake from single and mixed $\mathrm{Cd}, \mathrm{Pb}, \mathrm{Cu}$ and $\mathrm{Zn}$ spiked contaminated soils as well as their bioaccumulation in both the lower and upper roots and tillers of Vetiver grass.

\section{Materials and Methods}

\subsection{Site Descriptions and Experimental Design}

A pot experimental study was conducted in the greenhouse situated at the Rimba Ilmu, Institute of Biological Sciences, Faculty of Science, University of Malaya, Kuala Lumpur. Vetiver grass Vetiveria zizanioides (Linn.) Nash was selected for this experiment. Treatments included eight different types of single and mixed heavy metal spiked conditions (Table 1). All of the treatments were conducted under a completely randomized design (CRD) with three replications $(n=3)$.

\subsection{Soil Sampling and Sample Preparation}

Top soil $(0-20 \mathrm{~cm})$ was collected from a field located in the University of Malaya, Kuala Lumpur situated at the $3^{\circ} 7^{\prime} \mathrm{N}$ latitude and $101^{\circ} 39^{\prime} \mathrm{E}$ longitude. The preliminary physicochemical soil characterization (Table 2) was conducted before soils were air-dried for a week followed with passing through $<4 \mathrm{~mm}$ sieve to remove gravel and large non-soil objects. The dull reddish brown soil consists of $89.4 \%$ sand, $8.3 \%$ silt and $2.3 \%$ clay. Vetiver grass saplings were purchased from Humibox Malaysia and each fresh plant sapling with a uniform height $(20-25 \mathrm{~cm})$ was selected for this study. Each plant was grown in a plastic pot $(0.18 \mathrm{~m}$ diameter $\times 0.16 \mathrm{~m}$ depth) filled with two kilograms of soil, for all the treatments. All plants were watered evenly with $50 \mathrm{~mL}$ of tap water using a glass beaker once a day and their plant growth performance such as height, tiller number and percentage plant survivorship were continuously observed throughout the entire 60-day of the experiment.

The single and mixed heavy metal spiked treatments were prepared using cadmium nitrate tetrahydrate $\left[\mathrm{Cd}\left(\mathrm{NO}_{3}\right)_{2} \cdot 4 \mathrm{H}_{2} \mathrm{O}\right]$, lead (II) nitrate $\left[\mathrm{Pb}\left(\mathrm{NO}_{3}\right)_{2}\right]$, copper (II) sulfate $\left[\mathrm{CuSO}_{4}\right]$ and zinc sulfate heptahydrate $\left[\mathrm{ZnSO}_{4} \cdot 7 \mathrm{H}_{2} \mathrm{O}\right]$ salt compounds. The amended soil was then continuously stirred and incubated for two weeks to ensure the homogeneity of the desired single and mixed heavy metal treatments. The concentrations of both single and mixed heavy metal spiked treatments were determined based on the range of heavy metal concentrations exceeding the median permissible in the natural occurring levels by the Department of Environment,

Table 1 Design of treatment variables

\begin{tabular}{ll}
\hline Treatment & Spiked heavy metal $(\mathrm{mg} / \mathrm{kg})$ \\
\hline $\mathrm{Control}$ & No heavy metal added \\
$\mathrm{Cd}$ & $20 \mathrm{Cd}$ \\
$\mathrm{Pb}$ & $200 \mathrm{~Pb}$ \\
$\mathrm{Cu}$ & $100 \mathrm{Cu}$ \\
$\mathrm{Zn}$ & $200 \mathrm{Zn}$ \\
$\mathrm{Cd}+\mathrm{Pb}$ & $20 \mathrm{Cd}+200 \mathrm{~Pb}$ \\
$\mathrm{Cu}+\mathrm{Zn}$ & $100 \mathrm{Cu}+200 \mathrm{Zn}$ \\
$\mathrm{Cd}+\mathrm{Pb}+\mathrm{Cu}+\mathrm{Zn}$ & $20 \mathrm{Cd}+200 \mathrm{~Pb}+100 \mathrm{Cu}+200 \mathrm{Zn}$ \\
\hline
\end{tabular}


Table 2 Soil physico-chemical properties

\begin{tabular}{lll}
\hline Parameter (Unit) & & Mean \\
\hline Metal contents $(\mathrm{mg} / \mathrm{kg})$ & $\mathrm{Cd}$ & $0.87 \pm 0.08$ \\
& $\mathrm{~Pb}$ & $26.95 \pm 1.24$ \\
& $\mathrm{Cu}$ & $7.48 \pm 2.35$ \\
& $\mathrm{Zn}$ & $52.51 \pm 11.64$ \\
Soil texture & & 89.42 \\
Sand $(\%)$ & Very coarse sand $(\%)$ & 4.56 \\
& Coarse sand $(\%)$ & 39.15 \\
& Medium coarse sand $(\%)$ & 30.68 \\
& Fine sand $(\%)$ & 11.55 \\
Silt $(\%)$ & Very fine sand $(\%)$ & 3.48 \\
Clay $(\%)$ & & 8.27 \\
Temperature $\left({ }^{\circ} \mathrm{C}\right)$ & & 2.31 \\
pH & & $32.6 \pm 1.2$ \\
Colour $($ Munsell colour charts) & & $5.84 \pm 0.92$ \\
Water content $(\%)$ & $2.5 \mathrm{YR} 5 / 4$ \\
Field capacity $(\%)$ & $6.29 \pm 1.28$ \\
Saturation level $(\%)$ & Dull reddish brown & $35.16 \pm 4.82$ \\
Bulk density $\left(\mathrm{g} / \mathrm{cm}^{3}\right)$ & & 17.89 \\
Porosity $(\%)$ & & $1.96 \pm 0.35$ \\
\hline
\end{tabular}

Mean \pm standard deviation

Malaysia (DOE 2009), Canadian Council of Ministers of Environment (CCME 1999) and European Union (Lado et al. 2008) soil contamination guidelines.

\subsection{Soil and Plant Sample Analyses}

At the end of the 60-day of experiment, all freshly harvested plants were brought into the laboratory and washed in running filter water, followed by deionized water to remove any adhering soil particles before separating the plants into four different parts (lower and upper sections of roots and tillers) (Fig. 1). All plant samples were oven-dried for $72 \mathrm{~h}$ until obtaining a constant dry weight. The dry matter content $\left(\mathrm{g} / \mathrm{m}^{2}\right)$ of the plant samples was determined before homogenizing using a mortar and pestle. Approximately, $0.5 \mathrm{~g}$ of the homogenized dried samples underwent acid digestion with hydrochloric acid $(\mathrm{HCl})$, nitric acid $\left(\mathrm{HNO}_{3}\right)$ and hydrogen peroxide $\left(\mathrm{H}_{2} \mathrm{O}_{2}\right)$ according to Method 3050B (US EPA 1996) followed by Method 7000B (US EPA 2007) for the total recoverable elemental analysis using the Perkin-Elmer AAnalyst 400 flame atomic absorption spectrometer (F-AAS). The instrument's limit of detection was less than $0.01 \mathrm{mg} / \mathrm{L}$ for $\mathrm{Cd}$ and $0.1 \mathrm{mg} / \mathrm{L}$ for $\mathrm{Pb}, \mathrm{Cu}$ and $\mathrm{Zn}$. All chemicals used were of analytical reagent standard or of the best grade available. Similarly, soil samples were air-dried for $72 \mathrm{~h}$ until reaching a constant weight before analysis following the analytical procedures. The highly precise technique of chemical analysis was controlled using the Bundesanstalt für Materialforschung und -prüfung (BAM Germany): German Federal Institute for Materials Research and Testing (BRM\#12-mixed sandy soil) certified reference material with an average rate of metal recovery for $\mathrm{Cd}(102.7 \%), \mathrm{Pb}(98.4 \%), \mathrm{Cu}(93.2 \%)$ and $\mathrm{Zn}$ $(105.9 \%)$, respectively. 


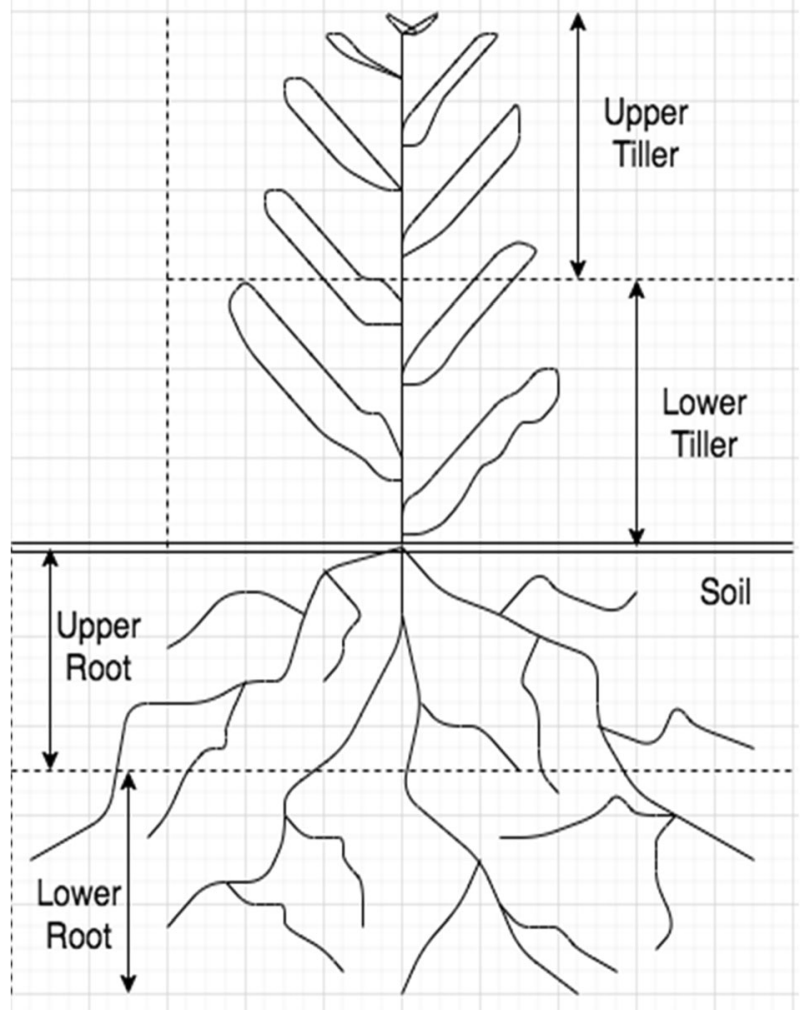

Fig. 1 Plant cross-section between the roots and shoots (tillers) of Vetiver grass

\subsection{Statistical Analysis and Data Processing}

The growth performance of Vetiver grass was evaluated using the root-tiller $(\mathrm{R} / \mathrm{T})$ ratio and tolerance index (TI) whilst the ability for metal accumulation and translocation upwards were evaluated by determining the translocation factor (TF), biological concentration factor (BCF), biological accumulation coefficient (BAC) and percentage of metal uptake efficacy (KabataPendias 2010; Alloway 2013; Ali et al. 2013), as follows:

$\mathrm{R} / \mathrm{T}$ ratio: $\quad$ Dry matter content in roots / Dry matter content in tillers

TI: $\quad$ Total dry matter content in heavy metal treatments / Total dry matter content in control

TF: $\quad$ Concentration of heavy metals in tillers / Concentration of heavy metals in roots

BCF: $\quad$ Concentration of heavy metals in roots / Concentration of heavy metals in soil

BAC: $\quad$ Concentration of heavy metals in tillers / Concentration of heavy metals in soil

Metal uptake efficacy [Concentration of heavy metals in tillers / Total concentration of heavy $(\%)$ : metals accumulated in Vetiver grass $] \times 100$ 
Both commonly used terminologies i.e., accumulation and concentration of heavy metals, are inter-connected and related to each other. The accumulation emphasizes on the outcome of heavy metal accumulated (found) whereby the concentration explains more precisely the amount and quantity of heavy metal ( $\mathrm{mg} / \mathrm{kg}$ ) obtained (accumulated) in the soil and/or plant section, respectively.

All experimental data were analysed by performing the one-way analysis of variance (ANOVA) and further statistical validity test for significant differences among treatment was conducted by employing the Fisher's least significant difference (LSD) tests at the $95 \%$ level of confidence with the aid of Microsoft Excel Office 365 versions 2016 software.

\section{Results}

\subsection{Responses of Plant Growth}

Soil $\mathrm{pH}$ was not significantly affected $(p>0.05)$ by the single and mixed spiked heavy metals in all Vetiver treatments (Fig. 2). During the 60-day of the experimental period, all Vetiver treatments recorded fluctuations in the soil $\mathrm{pH}$ between initial reading of 4.26-4.95 and final reading of 4.175.74. The control treatment recorded the highest $\mathrm{pH}$ of 5.74 while the lowest $\mathrm{pH}$ of 4.17 was observed in the $\mathrm{Cd}+\mathrm{Pb}$ treatment. The results obtained for both single and mixed spiked heavy metals did not considerably influence the overall soil $\mathrm{pH}$ changes in all treatments.

The relative growth of Vetiver grass in terms of plant height, tiller number and percentage survivorship varied among different types of single and mixed heavy metal spiked treatments (Table 3). There were no significant differences $(p>0.05)$ in the plant height observed among all single and mixed heavy metal spiked treatments compared with the control. Nevertheless, all of the single and mixed heavy metal spiked treatments recorded relatively lower plant height $(45.68-68.48 \mathrm{~cm})$ compared to the control $(76.88 \mathrm{~cm})$.

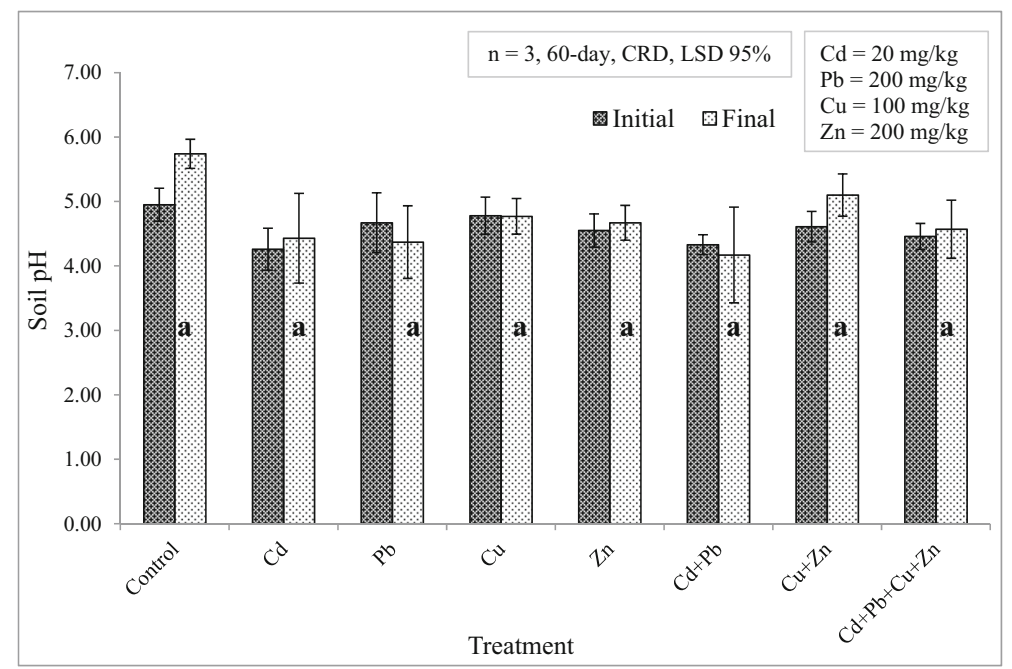

Fig. 2 Changes in soil $\mathrm{pH}$ of Vetiver grass in single and mixed heavy metal spiked treatments. Vertical bars represent standard deviation and common letters are not significantly different at the $95 \%$ level of confidence by LSD 
Table 3 Plant height $(\mathrm{cm})$, tiller number and plant survivorship $(\%)$ of Vetiver grass in single and mixed heavy metal spiked treatments

\begin{tabular}{llll}
\hline Treatment & Plant height $(\mathrm{cm})$ & Tiller number & Plant survivorship (\%) \\
\hline Control & $76.88 \pm 12.07 \mathrm{a}$ & $26.6 \pm 5.5 \mathrm{a}$ & $100.00 \pm 0.00 \mathrm{a}$ \\
$\mathrm{Cd}$ & $60.16 \pm 8.40 \mathrm{a}$ & $16.8 \pm 8.4 \mathrm{~b}$ & $97.33 \pm 14.21 \mathrm{a}$ \\
$\mathrm{Pb}$ & $68.48 \pm 20.83 \mathrm{a}$ & $21.6 \pm 11.4 \mathrm{ab}$ & $100.00 \pm 0.00 \mathrm{a}$ \\
$\mathrm{Cu}$ & $52.00 \pm 14.95 \mathrm{a}$ & $18.0 \pm 8.9 \mathrm{~b}$ & $81.94 \pm 5.72 \mathrm{ab}$ \\
$\mathrm{Zn}$ & $49.88 \pm 11.16 \mathrm{a}$ & $17.4 \pm 9.3 \mathrm{~b}$ & $78.67 \pm 13.66 \mathrm{~b}$ \\
$\mathrm{Cd}+\mathrm{Pb}$ & $64.48 \pm 9.05 \mathrm{a}$ & $19.6 \pm 7.3 \mathrm{ab}$ & $87.33 \pm 10.09 \mathrm{ab}$ \\
$\mathrm{Cu}+\mathrm{Zn}$ & $47.14 \pm 22.39 \mathrm{a}$ & $17.2 \pm 5.4 \mathrm{~b}$ & $77.34 \pm 23.45 \mathrm{~b}$ \\
$\mathrm{Cd}+\mathrm{Pb}+\mathrm{Cu}+\mathrm{Zn}$ & $45.68 \pm 17.73 \mathrm{a}$ & $12.2 \pm 7.7 \mathrm{~b}$ & $58.67 \pm 19.46 \mathrm{~b}$ \\
\hline
\end{tabular}

Mean \pm standard deviation and common letters are not significantly different at the $95 \%$ level of confidence using LSD

In contrast, the $\mathrm{Cd}, \mathrm{Cu}, \mathrm{Zn}, \mathrm{Zn}+\mathrm{Cu}$ and $\mathrm{Cd}+\mathrm{Pb}+\mathrm{Cu}+\mathrm{Zn}$ spiked treatments showed significantly lower $(p<0.05)$ tiller number compared to the control. The control recorded the highest tiller number of 26.6 while the lowest tiller number of 12.2 was observed in the $\mathrm{Cd}+$ $\mathrm{Pb}+\mathrm{Cu}+\mathrm{Zn}$ treatment. Similarly, with regard to plant survivorship, the $\mathrm{Zn}, \mathrm{Cu}+\mathrm{Zn}$ and $\mathrm{Cd}+$ $\mathrm{Pb}+\mathrm{Cu}+\mathrm{Zn}$ spiked treatments demonstrated significantly decreased $(p<0.05)$ percentage of survival compared with the control. Among all spiked treatments, both $\mathrm{Cu}+\mathrm{Zn}(77.34 \%)$ and $\mathrm{Cd}+\mathrm{Pb}+\mathrm{Cu}+\mathrm{Zn}(58.67 \%)$ mixed heavy metal treatments recorded the lowest percentage of survivorship.

The single $\mathrm{Cu}$ and $\mathrm{Zn}$ spiked treatments as well as the mixed $\mathrm{Cu}+\mathrm{Zn}$ and $\mathrm{Cd}+\mathrm{Pb}+\mathrm{Cu}+$ $\mathrm{Zn}$ spiked treatments exhibited significantly lower $(p<0.05)$ dry matter contents in both roots and tillers compared to the control (Table 4). All spiked treatments, with the exception of $\mathrm{Pb}$ treatment, showed significantly lower $(p<0.05)$ total dry matter content compared with the control. Between spiked treatments, both single $\mathrm{Cd}\left(15.50 \pm 1.22 \mathrm{~g} / \mathrm{m}^{2}\right)$ and $\mathrm{Pb}(17.14 \pm$ $0.69 \mathrm{~g} / \mathrm{m}^{2}$ ) spiked treatments recorded reasonably higher total dry matter content than the other mixed heavy metal treatments.

Both root-tiller $(\mathrm{R} / \mathrm{T})$ ratio and tolerance index $(\mathrm{TI})$ were employed to evaluate the tolerance ability of Vetiver grass growing under various single and mixed heavy metal spiked treatments.

Table 4 Dry matter content $\left(\mathrm{g} / \mathrm{m}^{2}\right)$, root-tiller ratio and tolerance index (TI) of Vetiver grass in single and mixed heavy metal spiked treatments

\begin{tabular}{llllll}
\hline Treatment & \multicolumn{3}{l}{ Dry matter content $\left(\mathrm{g} / \mathrm{m}^{2}\right)$} & & \\
\cline { 2 - 5 } & \multicolumn{2}{l}{ Vetiver } & & R/T ratio & TI \\
\cline { 2 - 5 } & Root & Tiller & Total & & \\
\hline $\mathrm{Control}$ & $8.01 \pm 1.37 \mathrm{a}$ & $11.17 \pm 2.87 \mathrm{a}$ & $19.18 \pm 3.01 \mathrm{a}$ & $0.751 \mathrm{a}$ & \\
$\mathrm{Cd}$ & $7.00 \pm 0.22 \mathrm{abc}$ & $8.51 \pm 1.21 \mathrm{ab}$ & $15.50 \pm 1.22 \mathrm{~b}$ & $0.833 \mathrm{a}$ & $0.817 \mathrm{ab}$ \\
$\mathrm{Pb}$ & $7.48 \pm 0.90 \mathrm{ab}$ & $9.66 \pm 1.18 \mathrm{a}$ & $17.14 \pm 0.69 \mathrm{ab}$ & $0.790 \mathrm{a}$ & $0.914 \mathrm{a}$ \\
$\mathrm{Cu}$ & $5.77 \pm 0.60 \mathrm{bc}$ & $5.95 \pm 1.61 \mathrm{bc}$ & $11.72 \pm 1.56 \mathrm{c}$ & $1.034 \mathrm{a}$ & $0.625 \mathrm{bcd}$ \\
$\mathrm{Zn}$ & $5.27 \pm 1.01 \mathrm{c}$ & $4.85 \pm 1.54 \mathrm{c}$ & $10.12 \pm 2.35 \mathrm{c}$ & $1.136 \mathrm{a}$ & $0.546 \mathrm{bcd}$ \\
$\mathrm{Cd}+\mathrm{Pb}$ & $6.82 \pm 0.76 \mathrm{abc}$ & $8.36 \pm 0.61 \mathrm{ab}$ & $15.19 \pm 1.30 \mathrm{~b}$ & $0.815 \mathrm{a}$ & $0.803 \mathrm{abc}$ \\
$\mathrm{Cu}+\mathrm{Zn}$ & $5.26 \pm 0.88 \mathrm{c}$ & $4.37 \pm 1.13 \mathrm{c}$ & $9.63 \pm 1.68 \mathrm{c}$ & $1.241 \mathrm{a}$ & $0.520 \mathrm{~cd}$ \\
$\mathrm{Cd}+\mathrm{Pb}+\mathrm{Cu}+\mathrm{Zn}$ & $5.24 \pm 1.65 \mathrm{c}$ & $4.34 \pm 0.97 \mathrm{c}$ & $9.58 \pm 0.70 \mathrm{c}$ & $1.321 \mathrm{a}$ & $0.506 \mathrm{~d}$ \\
\hline
\end{tabular}

Mean \pm standard deviation and common letters are not significantly different at the $95 \%$ level of confidence by LSD 
In terms of $\mathrm{R} / \mathrm{T}$ ratio, no significant difference $(p>0.05)$ was observed among all treatments. Nonetheless, among all the treatments, the single $\mathrm{Pb}$ spiked treatment showed the highest TI value of 0.914 while the lowest $\mathrm{TI}$ was recorded in the $\mathrm{Cd}+\mathrm{Pb}+\mathrm{Cu}+\mathrm{Zn}$ spiked treatment.

\subsection{Heavy Metal Uptake in Plant}

Tables 5 to 8 show the concentration of $\mathrm{Cd}, \mathrm{Pb}, \mathrm{Cu}$ and $\mathrm{Zn}$ accumulation in roots, tillers and their total for Vetiver grass in all single and mixed heavy metal spiked treatments. The accumulation of all four heavy metals in the lower and upper parts of the roots and tillers was comparatively variable. In terms of $\mathrm{Cd}$ (Table 5), all of the $\mathrm{Cd}, \mathrm{Cd}+\mathrm{Pb}$ and $\mathrm{Cd}+\mathrm{Pb}+$ $\mathrm{Cu}+\mathrm{Zn}$ spiked treatments showed significantly greater $(p<0.05) \mathrm{Cd}$ in both lower and upper roots and tillers of Vetiver grass compared to the control. Similarly, the $\mathrm{Cd}, \mathrm{Cd}+\mathrm{Pb}$ and $\mathrm{Cd}+$ $\mathrm{Pb}+\mathrm{Cu}+\mathrm{Zn}$ spiked treatments recorded significantly larger accumulation of $\mathrm{Cd}(p<0.05)$ in the total roots, total tillers and overall total among all other treatments. Unlike other types of heavy metals $(\mathrm{Pb}, \mathrm{Cu}$ and $\mathrm{Zn})$, the highest accumulation of $\mathrm{Cd}$ were recorded in the lower tillers for $\mathrm{Cd}+\mathrm{Pb}+\mathrm{Cu}+\mathrm{Zn}(62.53 \pm 5.97 \mathrm{mg} / \mathrm{kg})$ and $\mathrm{Cd}+\mathrm{Pb}(58.33 \pm 10.06 \mathrm{mg} / \mathrm{kg})$ spiked treatments. Between roots and tillers, $\mathrm{Cd}$ accumulation was considerably greater in roots than in tillers. The accumulation of $\mathrm{Cd}$ was relatively higher in the lower roots and lower tillers for $\mathrm{Cd}, \mathrm{Cd}+\mathrm{Pb}$ and $\mathrm{Cd}+\mathrm{Pb}+\mathrm{Cu}+\mathrm{Zn}$ spiked treatments compared with the upper plant parts, respectively. Nevertheless, the accumulation of $\mathrm{Cd}$ among various single and mixed $\mathrm{Cd}$ spiked treatments was in the order of $\mathrm{Cd}+\mathrm{Pb}+\mathrm{Cu}+\mathrm{Zn}>\mathrm{Cd}+\mathrm{Pb}>\mathrm{Cd}>>$ other spiked treatments.

With regard to $\mathrm{Pb}$ accumulation (Table 6), the $\mathrm{Pb}, \mathrm{Cd}+\mathrm{Pb}$ and $\mathrm{Cd}+\mathrm{Pb}+\mathrm{Cu}+\mathrm{Zn}$ spiked treatments exhibited significantly higher $(p<0.05) \mathrm{Pb}$ in both the lower and upper roots and tillers of Vetiver grass compared to the control. A significantly greater $(p<0.05) \mathrm{Pb}$ accumulation was demonstrated in the total root, total tiller and overall total accumulation for $\mathrm{Pb}$, $\mathrm{Cd}+\mathrm{Pb}$ and $\mathrm{Cd}+\mathrm{Pb}+\mathrm{Cu}+\mathrm{Zn}$ spiked treatments. The lower roots of $\mathrm{Cd}+\mathrm{Pb}+\mathrm{Cu}+\mathrm{Zn}$ $(177.67 \pm 20.01 \mathrm{mg} / \mathrm{kg})$ and $\mathrm{Cd}+\mathrm{Pb}(141.83 \pm 9.99 \mathrm{mg} / \mathrm{kg})$ spiked treatments recorded the highest accumulation of $\mathrm{Pb}$ among all the treatments.

Between roots and tillers, an appreciably higher accumulation of $\mathrm{Pb}$ was found in roots than in the tillers for all treatments. The accumulation of $\mathrm{Pb}$ was noticeably greater in the lower roots and lower tillers for both $\mathrm{Cd}+\mathrm{Pb}$ and $\mathrm{Cd}+\mathrm{Pb}+\mathrm{Cu}+\mathrm{Zn}$ spiked treatments compared with the upper plant parts, respectively whilst the vice versa trend was observed for $\mathrm{Pb}$ spiked treatment. However, among all single and mixed $\mathrm{Pb}$ spiked treatments, the accumulation trend for $\mathrm{Pb}$ was in the following order: $\mathrm{Cd}+\mathrm{Pb}+\mathrm{Cu}+\mathrm{Zn}>\mathrm{Cd}+\mathrm{Pb}>\mathrm{Pb}>>$ other spiked treatments.

$\mathrm{The} \mathrm{Cu}, \mathrm{Cu}+\mathrm{Zn}$ and $\mathrm{Cd}+\mathrm{Pb}+\mathrm{Cu}+\mathrm{Zn}$ spiked treatments recorded significantly higher $(p$ $<0.05$ ) accumulation of $\mathrm{Cu}$ in both the lower and upper roots and tillers of Vetiver grass compared to the control (Table 7). Similarly, the total root, total tiller and overall total accumulation for $\mathrm{Cu}, \mathrm{Cu}+\mathrm{Zn}$ and $\mathrm{Cd}+\mathrm{Pb}+\mathrm{Cu}+\mathrm{Zn}$ spiked treatments exhibited significantly greater $(p<0.05) \mathrm{Cu}$ than all other treatments. The lower roots $(365.64 \pm 27.00 \mathrm{mg} / \mathrm{kg})$ and upper roots $(308.03 \pm 10.74 \mathrm{mg} / \mathrm{kg})$ for $\mathrm{Cd}+\mathrm{Pb}+\mathrm{Cu}+\mathrm{Zn}$ spiked treatment recorded the highest accumulation of $\mathrm{Cu}$ among all the treatments. Between roots and tillers, the accumulation of $\mathrm{Cu}$ was substantially higher in roots than in tillers. The lower roots and lower tillers for $\mathrm{Cu}, \mathrm{Cu}+\mathrm{Zn}$ and $\mathrm{Cd}+\mathrm{Pb}+\mathrm{Cu}+\mathrm{Zn}$ spiked treatments accumulated reasonably higher $\mathrm{Cu}$ compared with the upper plant parts, respectively. The accumulation trend for $\mathrm{Cu}$ among all single and mixed $\mathrm{Cu}$ spiked treatments was in the order: $\mathrm{Cd}+\mathrm{Pb}+\mathrm{Cu}+\mathrm{Zn}>\mathrm{Cu}+\mathrm{Zn}>\mathrm{Cu}$ $>>$ other spiked treatments. 


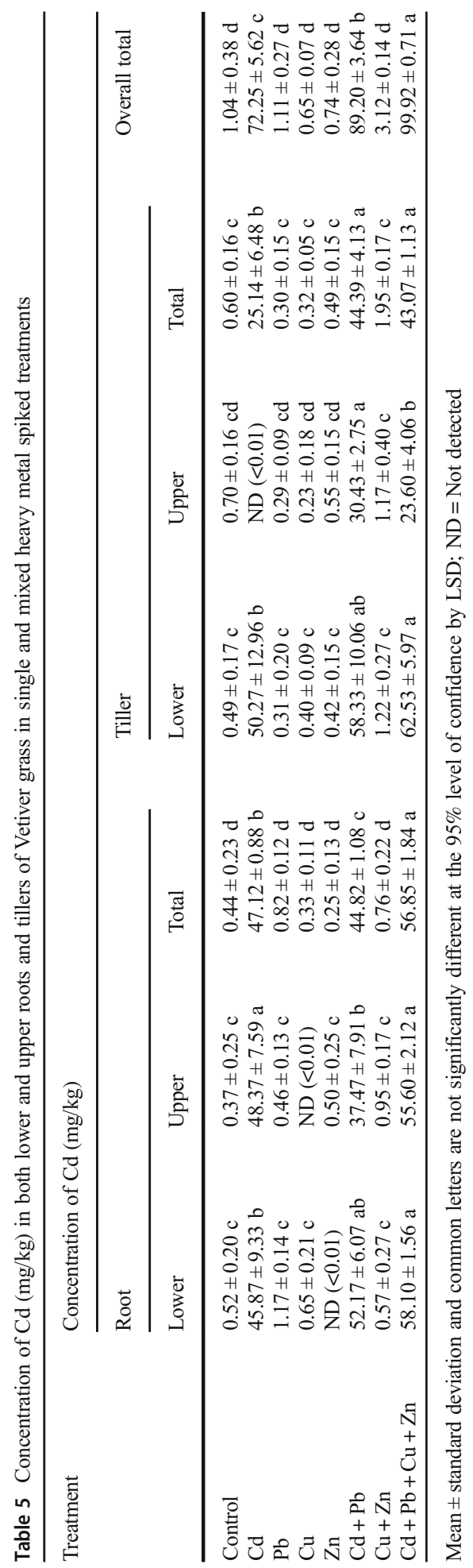




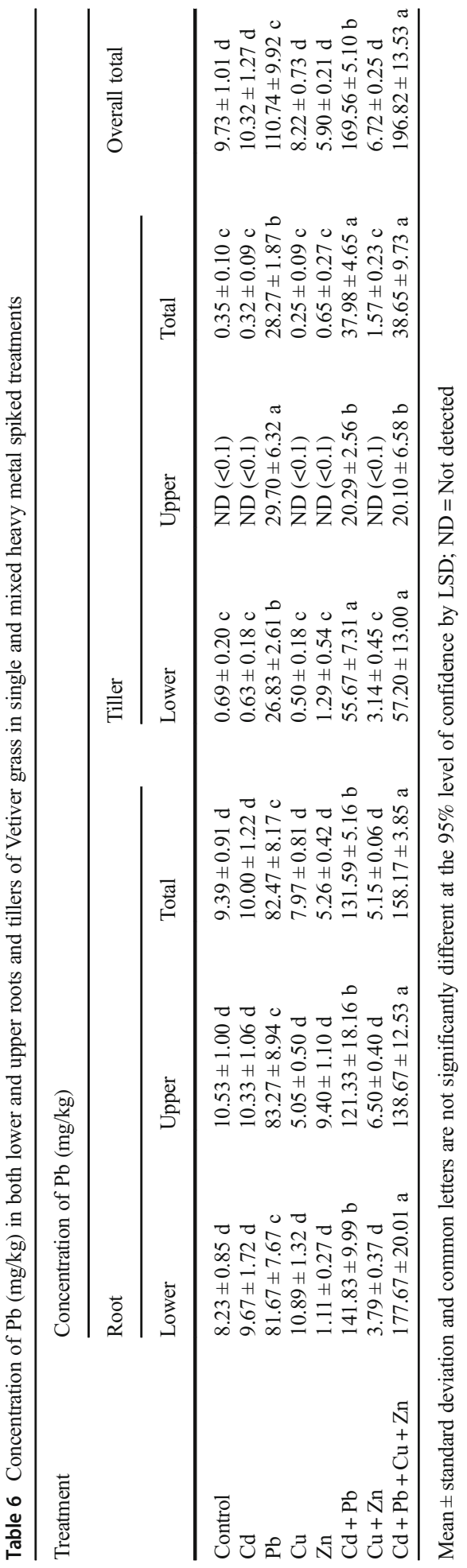




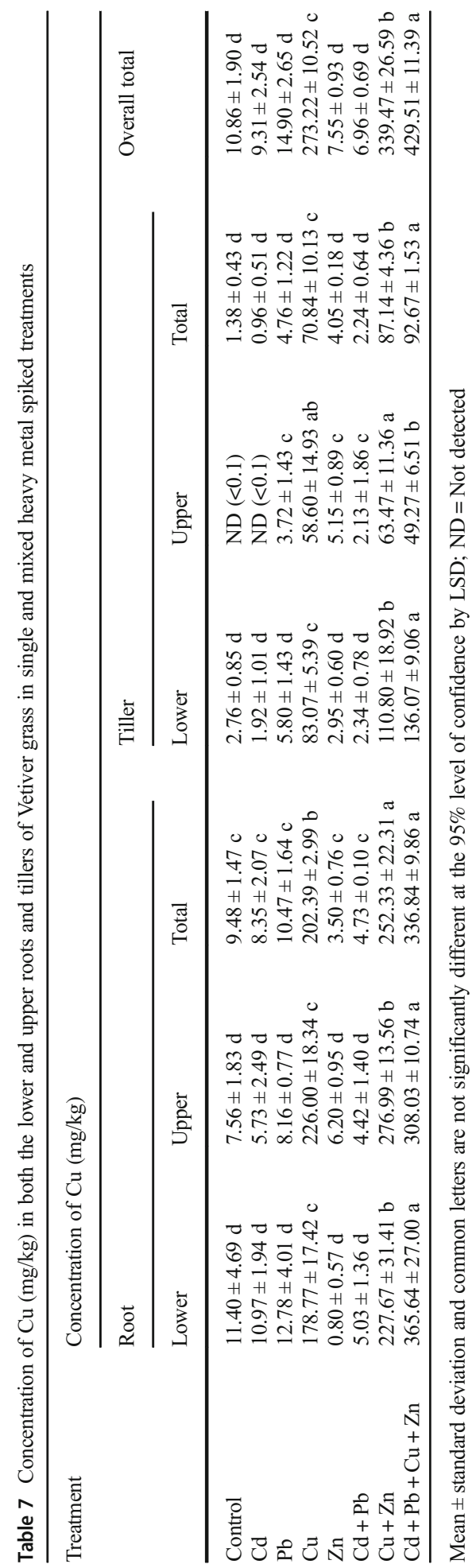




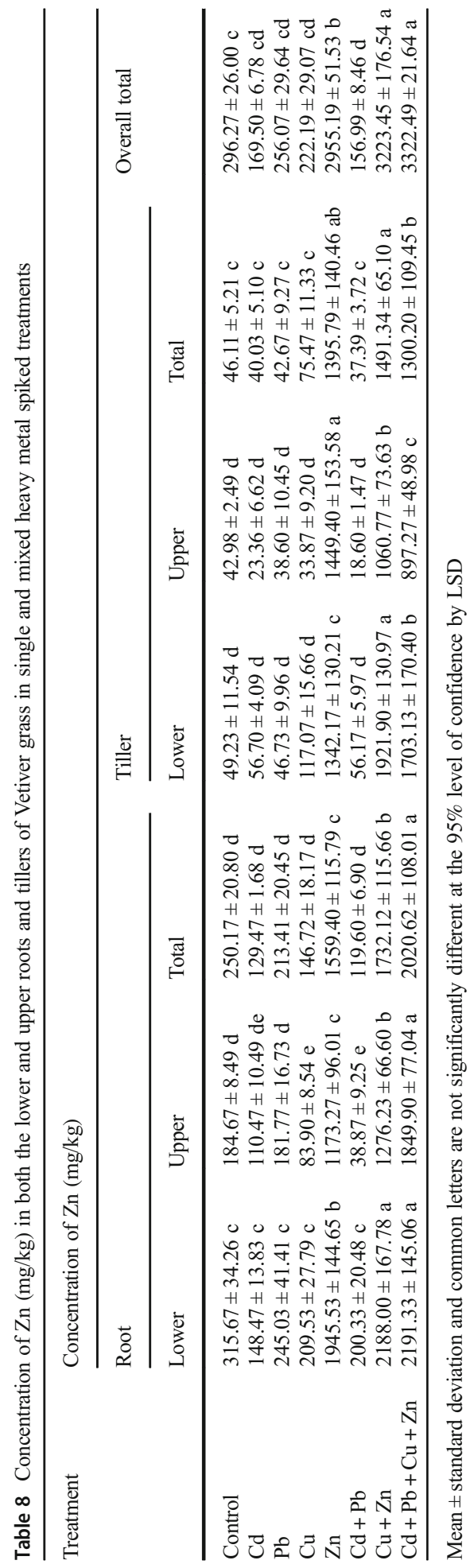


Similarly, in terms of $\mathrm{Zn}$ accumulation (Table 8), a significantly higher $(p<0.05)$ accumulation was found in both the lower and upper roots and tillers of Vetiver grass for $\mathrm{Zn}, \mathrm{Cu}+\mathrm{Zn}$ and $\mathrm{Cd}+\mathrm{Pb}+\mathrm{Cu}+\mathrm{Zn}$ spiked treatments compared to the control. A significantly greater $(p<$ $0.05)$ concentration of $\mathrm{Zn}$ was observed in the total roots, total tillers and overall total accumulation for $\mathrm{Zn}, \mathrm{Cu}+\mathrm{Zn}$ and $\mathrm{Cd}+\mathrm{Pb}+\mathrm{Cu}+\mathrm{Zn}$ spiked treatments than all other treatments. The lower roots of $\mathrm{Cd}+\mathrm{Pb}+\mathrm{Cu}+\mathrm{Zn}(2191.33 \pm 145.06 \mathrm{mg} / \mathrm{kg})$ and $\mathrm{Cu}+\mathrm{Zn}$ $(2188.00 \pm 167.78 \mathrm{mg} / \mathrm{kg})$ recorded the highest accumulation of $\mathrm{Zn}$ among all the treatments. Between roots and tillers, the $\mathrm{Zn}$ accumulation was noticeably greater in roots than in tillers. A considerably higher accumulation of $\mathrm{Zn}$ was recorded in the lower roots and lower tillers for $\mathrm{Zn}, \mathrm{Cu}+\mathrm{Zn}$ and $\mathrm{Cd}+\mathrm{Pb}+\mathrm{Cu}+\mathrm{Zn}$ spiked treatments compared with their upper plant parts, respectively. Among all single and mixed $\mathrm{Zn}$ spiked treatments, the accumulation of $\mathrm{Zn}$ was in the order of $\mathrm{Cd}+\mathrm{Pb}+\mathrm{Cu}+\mathrm{Zn}>\mathrm{Cu}+\mathrm{Zn}>\mathrm{Zn}>>$ other spiked treatments.

Based on the results obtained, the mixed $\mathrm{Cd}+\mathrm{Pb}+\mathrm{Cu}+\mathrm{Zn}$ spiked treatment accumulated the highest overall total amount of $\mathrm{Zn}(3322.49 \pm 21.64 \mathrm{mg} / \mathrm{kg})$ followed by $\mathrm{Cu}(429.51 \pm$ $11.39 \mathrm{mg} / \mathrm{kg}), \mathrm{Pb}(196.82 \pm 13.53 \mathrm{mg} / \mathrm{kg})$ and $\mathrm{Cd}(99.92 \pm 0.71 \mathrm{mg} / \mathrm{kg})$. The general trends of heavy metal accumulation for all treatments were in the order of $\mathrm{Zn}>>\mathrm{Cu}>\mathrm{Pb}>\mathrm{Cd}$ regardless of the total amount of spiked heavy metals in the soil. On the other hand, between single and mixed spiked treatments, the accumulation for mixed $\mathrm{Cd}+\mathrm{Pb}, \mathrm{Cu}+\mathrm{Zn}$ and $\mathrm{Cd}+$ $\mathrm{Pb}+\mathrm{Cu}+\mathrm{Zn}$ spiked treatments recorded remarkably higher accumulation compared to all of the single spiked treatments.

\subsection{Heavy Metal Translocation}

For all single and mixed spiked heavy metals biological concentration factors (BCF) as well as the biological accumulation coefficients (BAC), the translocation factors (TF) and the metal uptake efficacy (\%) are presented in Tables 9, 10, 11, 12 and 13.

Relatively higher BCF values were found in both lower and upper roots of all single and mixed $\mathrm{Cd}(1.873$ - 2.905), $\mathrm{Pb}(0.408-0.888), \mathrm{Cu}(1.788-3.656)$ and $\mathrm{Zn}(5.866$ - 10.957) spiked treatments, respectively, compared with other treatments. Among all the treatments, the lower roots for mixed $\mathrm{Cd}+\mathrm{Pb}+\mathrm{Cu}+\mathrm{Zn}$ spiked treatment exhibited the highest $\mathrm{BCF}$ value. Considering the $\mathrm{BCF}$ values $>1$ for $\mathrm{Cd}, \mathrm{Cu}$ and $\mathrm{Zn}$ accumulation, all single and mixed spiked

Table 9 Biological concentration factor $(\mathrm{BCF})$ of $\mathrm{Cd}, \mathrm{Pb}, \mathrm{Cu}$ and $\mathrm{Zn}$ accumulations in the lower and upper root of Vetiver grass in single and mixed heavy spiked metal treatments

\begin{tabular}{|c|c|c|c|c|c|c|c|c|}
\hline \multirow[t]{3}{*}{ Treatment } & \multicolumn{8}{|c|}{ BCF (Root) } \\
\hline & \multicolumn{2}{|c|}{ Cd accumulation } & \multicolumn{2}{|c|}{$\mathrm{Pb}$ accumulation } & \multicolumn{2}{|c|}{$\mathrm{Cu}$ accumulation } & \multicolumn{2}{|c|}{ Zn accumulation } \\
\hline & Lower & Upper & Lower & Upper & Lower & Upper & Lower & Upper \\
\hline Control & $0.594 \mathrm{~d}$ & $0.421 \mathrm{de}$ & $0.306 \mathrm{~d}$ & $0.391 \mathrm{bc}$ & $1.524 \mathrm{c}$ & $1.011 \mathrm{c}$ & $6.012 \mathrm{c}$ & $3.517 \mathrm{c}$ \\
\hline $\mathrm{Cd}$ & $2.293 \mathrm{~b}$ & $2.418 \mathrm{a}$ & $0.359 \mathrm{~cd}$ & $0.383 \mathrm{bc}$ & $1.467 \mathrm{c}$ & $0.766 \mathrm{~cd}$ & $2.827 \mathrm{e}$ & $2.104 \mathrm{~d}$ \\
\hline $\mathrm{Pb}$ & $1.341 \mathrm{c}$ & $0.529 \mathrm{~d}$ & $0.408 \mathrm{c}$ & $0.416 \mathrm{~b}$ & $1.709 \mathrm{bc}$ & $1.091 \mathrm{c}$ & $4.666 \mathrm{~d}$ & $3.462 \mathrm{c}$ \\
\hline $\mathrm{Cu}$ & $0.747 \mathrm{~d}$ & $0.011 \mathrm{e}$ & $0.404 \mathrm{~cd}$ & $0.188 \mathrm{~d}$ & $1.788 \mathrm{bc}$ & $2.260 \mathrm{~b}$ & $3.990 \mathrm{de}$ & $1.598 \mathrm{~d}$ \\
\hline $\mathrm{Zn}$ & $0.011 \mathrm{e}$ & $0.579 \mathrm{~d}$ & $0.041 \mathrm{f}$ & $0.349 \mathrm{bc}$ & $0.107 \mathrm{~d}$ & $0.829 \mathrm{~cd}$ & $9.728 \mathrm{~b}$ & $5.866 \mathrm{~b}$ \\
\hline $\mathrm{Cd}+\mathrm{Pb}$ & $2.608 \mathrm{ab}$ & $1.873 \mathrm{~b}$ & $0.709 \mathrm{~b}$ & $0.607 \mathrm{a}$ & $0.673 \mathrm{~d}$ & $0.591 \mathrm{~d}$ & $3.815 \mathrm{de}$ & $0.740 \mathrm{e}$ \\
\hline $\mathrm{Cu}+\mathrm{Zn}$ & $0.651 \mathrm{~d}$ & $1.088 \mathrm{c}$ & $0.141 \mathrm{e}$ & $0.241 \mathrm{~d}$ & $2.277 \mathrm{~b}$ & $2.770 \mathrm{a}$ & $10.940 \mathrm{a}$ & $6.381 \mathrm{~b}$ \\
\hline $\mathrm{Cd}+\mathrm{Pb}+\mathrm{Cu}+\mathrm{Zn}$ & $2.905 \mathrm{a}$ & $2.780 \mathrm{a}$ & $0.888 \mathrm{a}$ & $0.693 \mathrm{a}$ & $3.656 \mathrm{a}$ & $3.080 \mathrm{a}$ & $10.957 \mathrm{a}$ & $9.250 \mathrm{a}$ \\
\hline
\end{tabular}

Mean followed by common letters are not significantly different at the $95 \%$ level of confidence using LSD 
Table 10 Biological accumulation coefficient (BAC), translocation factor (TF) and metal uptake efficacy (\%) of $\mathrm{Cd}$ accumulation in the lower and upper tiller of Vetiver grass in single and mixed heavy metal spiked treatments

\begin{tabular}{|c|c|c|c|c|c|c|}
\hline \multirow[t]{3}{*}{ Treatment } & \multicolumn{6}{|c|}{ Cd accumulation } \\
\hline & \multicolumn{2}{|c|}{ BAC (Tiller) } & \multicolumn{2}{|c|}{ TF (Tiller) } & \multicolumn{2}{|c|}{ Efficacy (Tiller) } \\
\hline & Lower & Upper & Lower & Upper & Lower & Upper \\
\hline Control & $0.567 \mathrm{~d}$ & $0.808 \mathrm{~cd}$ & $0.597 \mathrm{ab}$ & $0.878 \mathrm{a}$ & $23.994 \mathrm{bc}$ & $35.014 \mathrm{a}$ \\
\hline $\mathrm{Cd}$ & $2.513 \mathrm{ab}$ & $0.001 \mathrm{f}$ & $0.535 \mathrm{~b}$ & $0.0001 \mathrm{~d}$ & $34.464 \mathrm{a}$ & $0.007 \mathrm{c}$ \\
\hline $\mathrm{Pb}$ & $0.352 \mathrm{~d}$ & 0.333 ef & $0.179 \mathrm{c}$ & $0.175 \mathrm{~cd}$ & $12.880 \mathrm{~d}$ & $12.892 \mathrm{~b}$ \\
\hline $\mathrm{Cu}$ & $0.464 \mathrm{~d}$ & $0.268 \mathrm{ef}$ & $0.625 \mathrm{ab}$ & $0.437 \mathrm{bc}$ & $31.198 \mathrm{ab}$ & $18.988 \mathrm{~b}$ \\
\hline $\mathrm{Zn}$ & $0.479 \mathrm{~d}$ & $0.636 \mathrm{de}$ & $0.848 \mathrm{ab}$ & $1.153 \mathrm{a}$ & $28.427 \mathrm{ab}$ & $38.444 \mathrm{a}$ \\
\hline $\mathrm{Cd}+\mathrm{Pb}$ & $2.917 \mathrm{ab}$ & $1.522 \mathrm{a}$ & $0.652 \mathrm{ab}$ & $0.339 \mathrm{~cd}$ & $32.601 \mathrm{a}$ & $17.091 \mathrm{~b}$ \\
\hline $\mathrm{Cu}+\mathrm{Zn}$ & $1.406 \mathrm{c}$ & $1.341 \mathrm{~b}$ & $0.885 \mathrm{a}$ & $0.809 \mathrm{ab}$ & $19.517 \mathrm{~cd}$ & $18.783 \mathrm{~b}$ \\
\hline $\mathrm{Cd}+\mathrm{Pb}+\mathrm{Cu}+\mathrm{Zn}$ & $3.127 \mathrm{a}$ & $1.180 \mathrm{bc}$ & $0.551 \mathrm{ab}$ & $0.207 \mathrm{~cd}$ & $31.306 \mathrm{ab}$ & $11.803 \mathrm{bc}$ \\
\hline
\end{tabular}

Mean followed by common letters are not significantly different at the $95 \%$ level of confidence using LSD

treatments accumulated appreciably higher metals in roots than tillers suggesting that the transfer of heavy metals from soils to roots was remarkably greater and roots acted as a sink for heavy metal accumulation.

The BAC, TF and metal efficacy were calculated to evaluate the capability and efficiency of heavy metal translocation from roots to tillers. Despite the relatively lower accumulation of all heavy metals in the tillers than in the roots, the BAC values $>1$ were recorded in both the lower and upper tillers for single and mixed Cd (1.180 - 3.127) as well as $\mathrm{Zn}(4.486$ - 9.610) spiked treatments. Based on the appreciably high BAC values $<1$ in both lower and upper tillers for single and mixed $\mathrm{Pb}(0.101-0.286)$ and $\mathrm{Cu}(0.493-0.831)$ spiked treatments, it is deduced that the translocation pathway for heavy metal accumulation from roots to tillers may be inhibited.

Similarly, with regard to $\mathrm{TF}$ values $<1$, the tolerably lower accumulation in both lower and upper tillers than in roots for all four different types of heavy metals suggested that the movement of metals from the roots to tillers were hindered. Even

Table 11 Biological accumulation coefficient (BAC), translocation factor (TF) and metal uptake efficacy (\%) of $\mathrm{Pb}$ accumulation in the lower and upper tiller of Vetiver grass in single and mixed heavy metal spiked treatments

\begin{tabular}{|c|c|c|c|c|c|c|}
\hline \multirow[t]{3}{*}{ Treatment } & \multicolumn{6}{|c|}{$\mathrm{Pb}$ accumulation } \\
\hline & \multicolumn{2}{|c|}{ BAC (Tiller) } & \multicolumn{2}{|c|}{ TF (Tiller) } & \multicolumn{2}{|c|}{ Efficacy (Tiller) } \\
\hline & Lower & Upper & Lower & Upper & Lower & Upper \\
\hline Control & $0.026 \mathrm{c}$ & $0.004 \mathrm{c}$ & $0.035 \mathrm{~d}$ & $0.005 \mathrm{c}$ & $3.499 \mathrm{~d}$ & $0.518 \mathrm{c}$ \\
\hline $\mathrm{Cd}$ & $0.023 \mathrm{c}$ & $0.004 \mathrm{c}$ & $0.030 \mathrm{~d}$ & $0.005 \mathrm{c}$ & $3.033 \mathrm{~d}$ & $0.490 \mathrm{c}$ \\
\hline $\mathrm{Pb}$ & $0.134 \mathrm{~b}$ & $0.149 \mathrm{a}$ & $0.123 \mathrm{bc}$ & $0.133 \mathrm{a}$ & $12.252 \mathrm{bc}$ & $13.318 \mathrm{a}$ \\
\hline $\mathrm{Cu}$ & $0.019 \mathrm{c}$ & $0.004 \mathrm{c}$ & $0.031 \mathrm{~d}$ & $0.006 \mathrm{c}$ & $3.110 \mathrm{~d}$ & $0.611 \mathrm{c}$ \\
\hline $\mathrm{Zn}$ & $0.048 \mathrm{c}$ & $0.004 \mathrm{c}$ & $0.110 \mathrm{c}$ & $0.008 \mathrm{c}$ & $10.968 \mathrm{c}$ & $0.848 \mathrm{c}$ \\
\hline $\mathrm{Cd}+\mathrm{Pb}$ & $0.278 \mathrm{a}$ & $0.101 \mathrm{~b}$ & $0.164 \mathrm{~b}$ & $0.060 \mathrm{~b}$ & $16.414 \mathrm{~b}$ & $5.974 \mathrm{~b}$ \\
\hline $\mathrm{Cu}+\mathrm{Zn}$ & $0.116 \mathrm{~b}$ & $0.004 \mathrm{c}$ & $0.233 \mathrm{a}$ & $0.007 \mathrm{c}$ & $23.297 \mathrm{a}$ & $0.745 \mathrm{c}$ \\
\hline $\mathrm{Cd}+\mathrm{Pb}+\mathrm{Cu}+\mathrm{Zn}$ & $0.286 \mathrm{a}$ & $0.101 \mathrm{~b}$ & $0.144 \mathrm{bc}$ & $0.050 \mathrm{~b}$ & $14.430 \mathrm{bc}$ & $5.047 \mathrm{~b}$ \\
\hline
\end{tabular}

Mean followed by common letters are not significantly different at the $95 \%$ level of confidence using LSD 
Table 12 Biological accumulation coefficient (BAC), translocation factor (TF) and metal uptake efficacy (\%) of $\mathrm{Cu}$ accumulation in the lower and upper tiller of Vetiver grass in single and mixed heavy metal spiked treatments

\begin{tabular}{|c|c|c|c|c|c|c|}
\hline \multirow[t]{3}{*}{ Treatment } & \multicolumn{6}{|c|}{$\mathrm{Cu}$ accumulation } \\
\hline & \multicolumn{2}{|c|}{ BAC (Tiller) } & \multicolumn{2}{|l|}{ TF (Tiller) } & \multicolumn{2}{|c|}{ Efficacy (Tiller) } \\
\hline & Lower & Upper & Lower & Upper & Lower & Upper \\
\hline Control & $0.369 \mathrm{~d}$ & $0.013 \mathrm{c}$ & $0.125 \mathrm{bc}$ & $0.005 \mathrm{~d}$ & $12.524 b c$ & $0.469 \mathrm{~d}$ \\
\hline $\mathrm{Cd}$ & $0.256 \mathrm{~d}$ & $0.013 \mathrm{c}$ & $0.099 \mathrm{c}$ & $0.006 \mathrm{~d}$ & $9.879 \mathrm{c}$ & $0.562 \mathrm{~d}$ \\
\hline $\mathrm{Pb}$ & $0.775 \mathrm{c}$ & $0.497 \mathrm{ab}$ & $0.190 \mathrm{ab}$ & $0.120 \mathrm{bc}$ & $18.979 \mathrm{ab}$ & $12.008 \mathrm{c}$ \\
\hline $\mathrm{Cu}$ & $0.831 \mathrm{c}$ & $0.586 \mathrm{a}$ & $0.152 \mathrm{abc}$ & $0.107 \mathrm{bc}$ & $15.194 \mathrm{abc}$ & $10.667 \mathrm{c}$ \\
\hline $\mathrm{Zn}$ & $0.394 \mathrm{~d}$ & $0.689 \mathrm{a}$ & $0.200 \mathrm{a}$ & $0.340 \mathrm{a}$ & $20.012 \mathrm{a}$ & $33.989 \mathrm{a}$ \\
\hline $\mathrm{Cd}+\mathrm{Pb}$ & $0.312 \mathrm{~d}$ & $0.285 \mathrm{~b}$ & $0.171 \mathrm{ab}$ & $0.147 \mathrm{~b}$ & $17.074 \mathrm{ab}$ & $21.515 \mathrm{~b}$ \\
\hline $\mathrm{Cu}+\mathrm{Zn}$ & $1.108 \mathrm{~b}$ & $0.635 \mathrm{a}$ & $0.162 \mathrm{abc}$ & $0.095 \mathrm{bc}$ & $16.246 \mathrm{abc}$ & $9.461 \mathrm{~cd}$ \\
\hline $\mathrm{Cd}+\mathrm{Pb}+\mathrm{Cu}+\mathrm{Zn}$ & $1.361 \mathrm{a}$ & $0.493 \mathrm{ab}$ & $0.158 \mathrm{abc}$ & $0.057 \mathrm{~cd}$ & $15.830 \mathrm{abc}$ & $5.749 \mathrm{~cd}$ \\
\hline
\end{tabular}

Mean followed by common letters are not significantly different at the $95 \%$ level of confidence using LSD

though the $\mathrm{TF}$ values were $<1$, fairly higher $\mathrm{TF}$ values in both lower and upper tillers than the other treatments were found for the accumulation of $\mathrm{Pb}(0.050-0.164)$ and Zn $(0.135-0.298)$.

The percentages of metal efficacy in both lower and upper tillers for $\mathrm{Pb}$ (5.047 $16.414 \%)$ and $\mathrm{Zn}(13.509$ - 29.800\%) accumulation for single and mixed spiked treatments were relatively higher compared with the other treatments, respectively. Despite the considerably lower accumulation of $\mathrm{Cd}$ found in tillers compared to the $\mathrm{Cu}$ and $\mathrm{Zn}$, the lower tillers for single (34.464\%) and mixed $(31.306-32.601 \%) \mathrm{Cd}$ spiked treatments recorded the highest percentages of $\mathrm{Cd}$ efficacy. Between single and mixed spiked heavy metal treatments, the single spiked treatments for all four different types of heavy metal recorded a relatively higher percentage of metal efficacy compared to the mixed spiked treatments. Nonetheless, the percentages of metal efficacy were remarkably higher in the lower tiller compared to the upper tiller for all four different types of heavy metals.

Table 13 Biological accumulation coefficient (BAC), translocation factor (TF) and metal uptake efficacy (\%) of $\mathrm{Zn}$ accumulation in the lower and upper tiller of Vetiver grass in single and mixed heavy metal spiked treatments

\begin{tabular}{|c|c|c|c|c|c|c|}
\hline \multirow[t]{3}{*}{ Treatment } & \multicolumn{6}{|c|}{ Zn accumulation } \\
\hline & \multicolumn{2}{|c|}{ BAC (Tiller) } & \multicolumn{2}{|c|}{ TF (Tiller) } & \multicolumn{2}{|c|}{ Efficacy (Tiller) } \\
\hline & Lower & Upper & Lower & Upper & Lower & Upper \\
\hline Control & $0.938 \mathrm{e}$ & $0.818 \mathrm{~d}$ & $0.082 \mathrm{e}$ & $0.073 \mathrm{~d}$ & $8.240 \mathrm{e}$ & $7.300 \mathrm{~d}$ \\
\hline $\mathrm{Cd}$ & $1.080 \mathrm{e}$ & $0.445 \mathrm{~d}$ & $0.167 \mathrm{~d}$ & $0.068 \mathrm{~d}$ & $16.714 \mathrm{~d}$ & $6.849 \mathrm{~d}$ \\
\hline $\mathrm{Pb}$ & $0.890 \mathrm{e}$ & $0.735 \mathrm{~d}$ & $0.091 \mathrm{e}$ & $0.075 \mathrm{~d}$ & $9.060 \mathrm{e}^{\circ}$ & $7.463 \mathrm{~d}$ \\
\hline $\mathrm{Cu}$ & $2.229 \mathrm{~d}$ & $0.645 \mathrm{~d}$ & $0.263 \mathrm{~b}$ & $0.076 \mathrm{~d}$ & $26.338 \mathrm{~b}$ & $7.588 \mathrm{~d}$ \\
\hline $\mathrm{Zn}$ & $6.711 \mathrm{c}$ & $7.247 \mathrm{a}$ & $0.227 \mathrm{c}$ & $0.245 \mathrm{a}$ & $22.701 \mathrm{c}$ & $24.506 \mathrm{a}$ \\
\hline $\mathrm{Cd}+\mathrm{Pb}$ & $1.070 \mathrm{e}$ & $0.354 \mathrm{~d}$ & $0.179 \mathrm{~d}$ & $0.059 \mathrm{~d}$ & $17.880 \mathrm{~d}$ & $5.926 \mathrm{~d}$ \\
\hline $\mathrm{Cu}+\mathrm{Zn}$ & $9.610 \mathrm{a}$ & $5.304 \mathrm{~b}$ & $0.298 \mathrm{a}$ & $0.165 \mathrm{~b}$ & $29.800 \mathrm{a}$ & $16.487 \mathrm{~b}$ \\
\hline $\mathrm{Cd}+\mathrm{Pb}+\mathrm{Cu}+\mathrm{Zn}$ & $8.516 \mathrm{~b}$ & $4.486 \mathrm{c}$ & $0.256 \mathrm{~b}$ & $0.135 \mathrm{c}$ & $25.643 \mathrm{~b}$ & $13.509 \mathrm{c}$ \\
\hline
\end{tabular}

Mean followed by common letters are not significantly different at the $95 \%$ level of confidence using LSD 


\section{Discussion}

The findings of this study indicated that soil $\mathrm{pH}$, plant heights and $\mathrm{R} / \mathrm{T}$ ratios of Vetiver grass were not affected with single and mixed spiked heavy metal treatments. Nonetheless, the results obtained for tiller number, percentage survivorship and dry matter content in Vetiver grass sharply declined among single and mixed spiked treatments compared to the control.

In the present study, $54.1 \%$ and $41.3 \%$ reductions were observed in the mixed $\mathrm{Cd}+\mathrm{Pb}+$ $\mathrm{Cu}+\mathrm{Zn}$ spiked treatment compared to the control in terms of both tiller number and percentage survivorship, respectively. The significant decrease in tiller number and percentage survivorship in Vetiver grass could be accounted for as a result of the combination application of mixed heavy metal, as was suggested by Chiu et al. (2006). In addition, studies by An et al. (2004) with cucumber (Cucumis sativus) also recorded similar findings of lower dry matter contents. However, Huang et al. (2009) reported the opposite results for paddy rice plant (Oryza sativa L.) where single and mixed spiked heavy metals accumulations were applied.

In contrast to $\mathrm{Pb}, \mathrm{Cu}$ and $\mathrm{Zn}$ accumulations, there was no accumulation of $\mathrm{Cd}$ found in the upper tiller for $\mathrm{Cd}$ spiked treatment. The highest accumulation of $\mathrm{Cd}$ was recorded in the lower tiller compared to root parts for all mixed spiked treatments, unlike other heavy metals. This trend was supported by earlier studies undertaken by Aibibu et al. (2010), Zhang et al. (2014), Christofilopoulos et al. (2016) and Phusantisampan et al. (2016) whereby generally, most of $\mathrm{Cd}$ were more likely to be accumulated in roots compared to tillers. These findings highlighted the fact that Vetiver grass could be a potential Cd phyto-stabilizer with regard to its high accumulation capability in both roots and tillers with $\mathrm{BCF}$ and $\mathrm{BAC}$ values $>1$ for single $\mathrm{Cd}$ as well as for mixed $\mathrm{Cd}+\mathrm{Pb}$ and $\mathrm{Cd}+\mathrm{Pb}+\mathrm{Cu}+\mathrm{Zn}$ spiked treatments.

Similarly, the high BCF values of $>1$ in both lower and upper roots demonstrated positive characteristics of phyto-stabilization for all heavy metal treatments. Generally, there are numerous categories of phyto-remediation technology depending on the different types of plants and levels of clean-up required (Padmavathiamma and Li 2007; Tangahu et al. 2011). Phyto-extraction refers to the bioaccumulation and translocation uptake of metal contaminants in the soil via roots into the above ground components (Nascimento et al. 2006; Sheoran et al. 2016). On the other hand, phyto-stabilization uses the plant to immobilize metal contaminants in soil through bioaccumulation and adsorption by roots within the root zones (Berti and Cunningham 2000; Mahar et al. 2016).

Over the past decades, there have been limited studies with emphasis on the comparison between single and mixed heavy metal accumulation in plants. This study demonstrated complex interactions in single and mixed spiked treatments, affecting the overall heavy metal accumulation trends in Vetiver grass. Similar effects of single and mixed spiked treatments were reported by Peralta-Videa et al. (2002), Zhou et al. (2014), Wuana et al. (2016), He et al. (2016), Yang et al. (2016) and Chirakkara et al. (2016). They contributed to the metal accumulation in alfalfa, castor and paddy rice. Compared to the works of Duo et al. (2010), this study was further expanded to cover separate parts of the lower and upper roots and tillers of Vetiver grass in order to provide a more comprehensive phyto-assessment for translocation of heavy metals from the lower root upwards to the top of the tiller.

Notwithstanding, it is important to note that the mixed heavy metal spiked soils showed more complex interaction than with only a single metal contamination. The presence of more than one heavy metal in the soil would possibly affect the overall phyto-remediation ability in the plants (Chirakkara et al. 2016). Many recent studies by Ramamurthy and Memarian (2014), Hechmi et al. (2014) and Chigbo and Batty (2015) reported that the use of two and 
more different types of soil contaminants could unexpectedly limit their mobility and bioavailability resulting in reduction of phyto-accumulation efficiency in plants. However, this study demonstrated findings to the contrary, with Vetiver grass showing substantially high phyto-accumulation ability under mixed metal spiked treatments as compared to single heavy metal spiked treatments. This scenario is possible as the fates and translocation of metal contaminants under the mixed heavy metal conditions are complex and unpredictable (Reddy 2011). As a result, this study indicates that the presence and combination of different types of heavy metals due to the physico-chemical interactions among metals in the soil and/or within the plant species, may lead to the higher accumulation in all mixed heavy metal treatments as correspondingly observed by Chirakkara et al. (2016).

\section{Conclusions}

Vetiver grass grown in mixed $\mathrm{Cd}+\mathrm{Pb}, \mathrm{Cu}+\mathrm{Zn}$ and $\mathrm{Cd}+\mathrm{Pb}+\mathrm{Cu}+\mathrm{Zn}$ spiked treatments was potentially capable of accumulating higher heavy metals than single spiked treatments, in the order of $\mathrm{Zn}>>\mathrm{Cu}>\mathrm{Pb}>\mathrm{Cd}$. Vetiver grass may be regarded as a promising $\mathrm{Cd}, \mathrm{Cu}$ and $\mathrm{Zn}$ phyto-stabilizer due to its high BCF values of $>1$ and noticeably higher accumulation in roots compared to tillers. In terms of different plant parts, the lower roots and lower tillers of Vetiver grass exhibited a strong tendency for greater uptake and accumulation of all four heavy metals, irrespective of single and/or mixed spiked treatments.

Funding Information This research was supported by the funding provided by the University of Malaya, Kuala Lumpur (PG006-2013A and RK001-2016) and the Malaysia Toray Science Foundation (STRG15/G251) grants.

\section{References}

Aibibu N, Liu Y, Zeng G, Wang X, Chen B, Song H, Xu L (2010) Cadmium accumulation in Vetiveria zizanioides and its effects on growth, physiological and biochemical characters. Bioresour Technol 101: 6297-6303

Ali H, Khan E, Sajad MA (2013) Phytoremediation of heavy metals - concepts and applications. Chemosphere 91:869-881

Ali H, Khan E (2017) Environmental chemistry in the twenty-first century. Environ Chem Lett 15:329-346

Ali H, Khan E (2018a) What are heavy metals? Long-standing controversy over the scientific use of the term 'heavy metals': proposal of a comprehensive definition. Toxicol Environ Chem 100:6-19

Ali H, Khan E (2018b) Trophic transfer, bioaccumulation, and biomagnification of non-essential hazardous heavy metals and metalloids in food chains/webs:concepts and implications for wildlife and human health. Hum Ecol Risk Assess:1-24

Ali H, Khan E, Ilahi I (2019) Environmental chemistry and ecotoxicology of hazardous heavy metals: environmental persistence, toxicity, and bioaccumulation. Aust J Chem 2019:6730305

Alloway BJ (2013) Sources of heavy metals and metalloids in soils. In: Heavy metals in soils, Springer, Netherlands, pp 11-50

An YJ, Kim YM, Kwon TI, Jeong SW (2004) Combined effect of copper, cadmium, and lead upon Cucumis sativus growth and bioaccumulation. Sci Total Environ 326:85-93

Antonovics J, Bradshaw AD, Turner RG (1971) Heavy metal tolerance in plants. Adv Ecol Res 7:1-85

Azam MM (2016) Soil contamination and remediation measures: revisiting the relevant laws and institutions. In: Environmental remediation technologies for metal-contaminated soils. Springer, Tokyo, pp 99-124. https://link.springer.com/chapter/10.1007/978-4-431-55759-3_5

Berti WR, Cunningham SD (2000) Phytostabilization of metals. In: Raskin I, Ensley BD (eds), Phytoremediation of Toxic Metals: Using Plants to Clean-up the Environment, John Wiley and Sons, New York, pp 71-88 
Bradl H (ed) (2005) Heavy Metals in the Environment: Origin, Interaction and Remediation, Vol 6. Academic Press, Amsterdam, p 282. https://epdf.pub/heavy-metals-in-the-environment-origin-interaction-andremediation-volume-6-inte.html

Brümmer GW (1986) Heavy Metal Species, Mobility and Availability in Soils. Springer, Berlin Heidelberg, pp 169-192

CCME, Canadian Council of Ministers of the Environment (1999) Canadian soil quality guidelines for the protection of environmental and human health. Canadian Environmental Quality Guidelines, Canada

Chen Y, Shen Z, Li X (2004) The use of vetiver grass (Vetiveria zizanioides) in the phytoremediation of soils contaminated with heavy metals. Appl Geochem 19:1553-1565

Chigbo C, Batty L (2015) Chelate-assisted phytoremediation of cu-pyrene-contaminated soil using Z. mays. Water, Air, Soil Pollut 226:1-10

Chirakkara RA, Cameselle C, Reddy KR (2016) Assessing the applicability of phytoremediation of soils with mixed organic and heavy metal contaminants. Rev Environ Sci Biotechnol 15:299-326

Chiu KK, Ye ZH, Wong MH (2006) Growth of Vetiveria zizanioides and Phragmities australis on $\mathrm{Pb} / \mathrm{Zn}$ and cu mine tailings amended with manure compost and sewage sludge: a greenhouse study. Bioresour Technol 97: $158-170$

Christofilopoulos S, Syranidou E, Gkavrou G, Manousaki E, Kalogerakis N (2016) The role of halophyte Juncus acutus L. in the remediation of mixed contamination in a hydroponic greenhouse experiment. J Chem Technol Biotechnol 91:1665-1674

Clemens S, Ma JF (2016) Toxic heavy metal and metalloid accumulation in crop plants and foods. Annu Rev Plant Biol 67:489-512

Danh LT, Truong P, Mammucari R, Tran T, Foster N (2009) Vetiver grass, Vetiveria zizanioides: a choice plant for phytoremediation of heavy metals and organic wastes. Int J Phytorem 11:664-691

Darajeh N, Truong P, Rezania S, Alizadeh H, Leung DW (2019) Effectiveness of Vetiver grass versus other plants for phytoremediation of contaminated water. J Environ Treat Tech 7:485-500

DOE, Malaysian Department of Environment (2009) Contaminated land management and control guidelines No. 1: Malaysian recommended site screening levels for contaminated land. Department of Environment, Ministry of Natural Resources and Environment, Putrajaya

Doran JW (2002) Soil health and global sustainability: translating science into practice. Agric Ecosyst Environ 88:119-127

Duo LA, Lian F, Zhao SL (2010) Enhanced uptake of heavy metals in municipal solid waste compost by turfgrass following the application of EDTA. Environ Monit Assess 165:377-387

Garbisu C, Alkorta I (2003) Basic concepts on heavy metal soil bioremediation. Eur J Miner Process Environ Prot 3:58-66

Ghadiri S, Farpoor MH, Mehrizi MH (2018) Phytoremediation of soils polluted by heavy metals using Vetiver grass and tall fescue. Desert 23:123-132

Gnansounou E, Alves CM, Raman JK (2017) Multiple applications of vetiver grass - a review. Int J Environ Sci $2: 125-141$

Gomes HI (2012) Phytoremediation for bioenergy: challenges and opportunities. Environ Technol Rev 1:59-66

Gómez-Sagasti MT, Epelde L, Alkorta I, Garbisu C (2016) Reflections on soil contamination research from a biologists point of view. Appl Soil Ecol 105:207-210

Harris MR, Herbert SM, Smith MA (1995) Remedial treatment for contaminated land (vol 9): in-situ methods of remediation. Construction Industry Research and Information Association (CIRIA) Special Publication, London

Hasegawa H, Rahman IMM, Rahman MA (eds) (2016) Environmental Remediation Technologies for Netalcontaminated Soils. Springer, Tokyo

He H, Tam NF, Yao A, Qiu R, Li WC, Ye Z (2016) Effects of alkaline and bioorganic amendments on cadmium, lead, zinc, and nutrient accumulation in brown rice and grain yield in acidic paddy fields contaminated with a mixture of heavy metals. Environ Sci Pollut Res 23:23551-23560

Hechmi N, Aissa NB, Abdenaceur H, Jedidi N (2014) Evaluating the phytoremediation potential of Phragmites australis grown in pentachlorophenol and cadmium co-contaminated soils. Environ Sci Pollut Res 21:1304-1313

Huang Y, Hu Y, Liu Y (2009) Heavy metal accumulation in iron plaque and growth of rice plants upon exposure to single and combined contamination by copper, cadmium and lead. Acta Ecol Sin 29:320-326

Kabata-Pendias A (2010) Trace Elements in Soils and Plants. CRC, Boca Raton

Kamal AKI, Islam MR, Hassan M, Ahmed F, Rahman MAT, Moniruzzaman M (2016) Bioaccumulation of trace metals in selected plants within Amin bazar landfill site, Dhaka, Bangladesh. Environ Process 3:179-194

Khalil MA, Abdel-Lateif HM, Bayoumi BM, van Straalen NM (1996) Analysis of separate and combined effects of heavy metals on the growth of Aporrectodea caliginosa (Oligochaeta; Annelida), using the toxic unit approach. Appl Soil Ecol 4:213-219 
Lado LR, Hengl T, Reuter HI (2008) Heavy metals in European soils: a geostatistical analysis of the FOREGS geochemical database. Geoderma 148:189-199

Mahar A, Wang P, Ali A, Awasthi MK, Lahori AH, Wang Q, Li R, Zhang Z (2016) Challenges and opportunities in the phytoremediation of heavy metals contaminated soils: a review. Ecotoxicol Environ Saf 126:111-121

Martin S, Griswold W (2009) Human health effects of heavy metals. Environ Sci Technol Briefs Citizens 15:1-6

Meuser H (2010) Causes of soil contamination in the urban environment. In: Meuser H (ed) Contaminated Urban Soils. Springer, Dordrecht, pp 29-94

Nagajyoti PC, Lee KD, Sreekanth TVM (2010) Heavy metals, occurrence and toxicity for plants: a review. Environ Chem Lett 8:199-216

Nascimento CWA, Amarasiriwardena D, Xing B (2006) Comparison of natural organic acids and synthetic chelates at enhancing phytoextraction of metals from a multi-metal contaminated soil. Environ Pollut 140:114-123

Ng CC, Boyce AN, Rahman M, Abas R (2017) Tolerance threshold and phyto-assessment of cadmium and lead in vetiver grass, Vetiveria zizanioides (Linn.) Nash. Chiang Mai J Sci 44:1367-1378

Ng CC, Boyce AN, Rahman MM, Abas MR, Mahmood NZ (2018) Phyto-evaluation of Cd-Pb using tropical plants in soil-leachate conditions. Air Soil Water Res 11:1-9

Ng CC, Boyce AN, Abas MR, Mahmood NZ, Han F (2019) Phytoassessment of Vetiver grass enhanced with EDTA soil amendment grown in single and mixed heavy metal-contaminated soil. Environ Monit Assess 191:434

Padmavathiamma PK, Li LY (2007) Phytoremediation technology: hyper-accumulation metals in plants. Water, Air, Soil Pollut 184:105-126

Peralta-Videa JR, Gardea-Torresdey JL, Gomez E, Tiemann KJ, Parsons JG, Carrillo G (2002) Effect of mixed cadmium, copper, nickel and zinc at different pHs upon alfalfa growth and heavy metal uptake. Environ Pollut 119:291-301

Phusantisampan T, Meeinkuirt W, Saengwilai P, Pichtel J, Chaiyarat R (2016) Phytostabilization potential of two ecotypes of Vetiveria zizanioides in cadmium-contaminated soils: greenhouse and field experiments. Environ Sci Pollut Res 23:20027-20038

Pilbeam DJ, Barker AV (2007) Handbook of plant nutrition. CRC Press, Boca Raton

Raman JK, Gnansounou E (2018) A review on bioremediation potential of vetiver grass. In Waste bioremediation, Springer, Singapore, pp 127-140

Ramamurthy AS, Memarian R (2014) Chelate enhanced phytoremediation of soil containing a mixed contaminant. Environ Earth Sci 72:201-206

Reddy KR (2011) Special issue on contaminant mixtures: fate, transport, and remediation. J Hazard Toxic Radioact Waste 15:128-129

Sheoran V, Sheoran AS, Poonia P (2016) Factors affecting phytoextraction: a review. Pedosphere 26:148-166

Stolpe C, Müller C (2016) Effects of single and combined heavy metals and their chelators on aphid performance and preferences. Environ Toxicol Chem 35:3023-3030

Storelli MM (2008) Potential human health risks from metals $(\mathrm{Hg}, \mathrm{Cd}$, and $\mathrm{Pb}$ ) and polychlorinated biphenyls (PCBs) via seafood consumption: estimation of target hazard quotients (THQs) and toxic equivalents (TEQs). Food Chem Toxicol 46:2782-2788

Tangahu BV, Sheikh Abdullah SR, Basri H, Idris M, Anuar N, Mukhlisin M (2011) A review on heavy metals (As, $\mathrm{Pb}$, and $\mathrm{Hg}$ ) uptake by plants through phytoremediation. Int J Chem Eng 2011:1-31

Truong P, Danh LT (2015) The vetiver system for improving water quality: prevention and treatment of contaminated water and land ( 2 ed), The Vetiver Network International, San Antonio, TX, USA. https://www.vetiver.org/TVN_Water_quality\%202\%20ed.pdf

US EPA, United States of America Environmental Protection Agency (1996) Method 3050B: acid digestion of sediments, sludges and soils. Environmental Protection Agency, Washington, DC

US EPA, United States of America Environmental Protection Agency (2007) Method 7000B flame atomic absorption spectrophotometry. Environmental Protection Agency, Washington, DC

Van der Perk M (2013) Soil and Water Contamination. CRC Press, Boca Raton

Waller RM (1982) Ground water and the rural homeowner. United States Geological Survey, Colorado

Wuana RA, Okieimen FE (2011) Heavy metals in contaminated soils: a review of sources, chemistry, risks and best available strategies for remediation. ISRN Ecol 2011:1-20

Wuana RA, Eneji IS, Naku JU (2016) Single and mixed chelants-assisted phytoextraction of heavy metals in municipal waste dump soil by castor. Adv Environ Res 5:19-35

Yang J, Tang C, Wang F, Wu Y (2016) Co-contamination of Cu and Cd in paddy fields: using periphyton to entrap heavy metals. J Hazard Mater 304:150-158

Zhang X, Gao B, Xia H (2014) Effect of cadmium on growth, photosynthesis, mineral nutrition and metal accumulation of bana grass and vetiver grass. Ecotoxicol Environ Saf 106:102-108

Zhou H, Zhou X, Zeng M, Liao BH, Liu L, Yang WT, Wu YM, Qiu QY, Wang YJ (2014) Effects of combined amendments on heavy metal accumulation in rice (Oryza sativa L.) planted on contaminated paddy soil. Ecotoxicol Environ Saf 101:226-232 
Publisher's Note Springer Nature remains neutral with regard to jurisdictional claims in published maps and institutional affiliations.

\section{Affiliations}

\section{Chuck Chuan $\mathrm{Ng}^{1,2,3} \cdot$ Amru Nasrulhaq Boyce ${ }^{2} \cdot$ Mhd Radzi Abas $^{4} \cdot$ Noor Zalina Mahmood $^{2}$. Fengxiang Han ${ }^{3}$}

1 School of Biological Sciences, Faculty of Science and Technology, Quest International University Perak, 30250 Ipoh, Perak, Malaysia

2 Institute of Biological Sciences, Faculty of Science, University of Malaya, 50603 Kuala Lumpur, Malaysia

3 Department of Chemistry and Biochemistry, College of Science, Engineering and Technology, Jackson State University, Jackson, MS 39217, USA

4 Chemistry Department, Faculty of Science, University of Malaya, 50603 Kuala Lumpur, Malaysia 